Article

\title{
Unintentional Consent
}

\section{Terence Rajivan Edward}

\begin{abstract}
Some political philosophers have judged that it is absurd to think that there can be unintentional consent. In this paper, I present an example of unintentional consent, which I refer to as the adapted boardroom example. I consider reasons for denying that this is an example of unintentional consent but find that these reasons are unconvincing.
\end{abstract}

Keywords: Simmons, consent, unintentional consent, tacit consent

\section{Introduction}

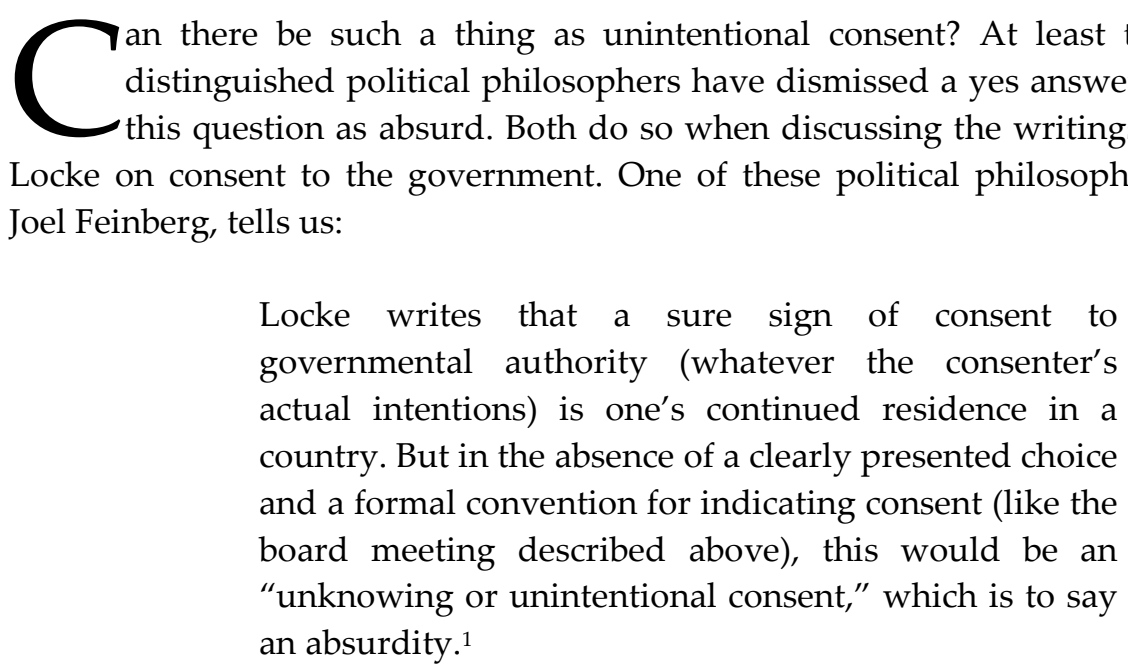

The other political philosopher is A. John Simmons, who tells us:

${ }^{1}$ Joel Feinberg, "Civil Disobedience in the Modern World," in Freedom and Fulfilment: Philosophical Essays (Princeton: Princeton University Press, 1994), 167.

(C) 2015 Terence Rajivan Edward

http://www.kritike.org/journal/issue 16/edward june2015.pdf

ISSN 1908-7330 
... Locke's suggestion that binding consent can be given unintentionally is a patent absurdity. ${ }^{2}$

I do not agree that it is absurd to suppose that there can be unintentional consent. Indeed, I suppose that there can be. ${ }^{3}$ This paper focuses on the work of Simmons, specifically his article 'Tacit Consent and Political Obligation,' in order to contest the judgment that this is absurd.

\section{A Definition and Two Answers}

Why say that it is absurd to suppose that there can be unintentional consent? To say this is to say that unintentional consent is obviously impossible. Those who make this claim do not spell out the thinking behind it. It is important to do so because there is an immediate objection to the claim. The objection is that one can unintentionally consent to $\mathrm{X}$ by intentionally signing a contract but failing to read the small print which specifies $\mathrm{X}$ as something being consented to by signatories.

In response to this objection, it may be said that a case of this kind actually counts as intentional consent. What then is unintentional consent? Unintentional consent, it may be proposed, is to be understood as follows:

A person unintentionally consents to $\mathrm{X}$ if, and only if, two conditions are met. Firstly, they consent to $X$ without intending to. Secondly, they have not intentionally consented to something (e.g., a contract), which specifies in its content that those who consent to this thing are thereby consenting to $\mathrm{X}$.

The second condition is there to rule out the small print cases described in the previous paragraph. I will work with this definition below. (For how well it fits with the literature on 'unintentional,' see the terminological note at the end of this paper.)

Working with the definition, we can readily anticipate two answers to the question of why it is absurd to suppose that there are any genuine

2 A. John Simmons, "Tacit Consent and Political Obligation," in Philosophy and Public Affairs, 5:3 (1976), 282.

${ }^{3}$ The material I offer to counter dismissals of unintentional consent also challenges Joseph Raz's account of consent. Raz says that consent is given by behaviour that is undertaken in the belief that it will change the normative situation of another and in the belief that observers will realize this, but I offer an example which casts doubt on this assertion. See Joseph Raz, The Morality of Freedom (Oxford: Clarendon Press, 1986), 81.

(c) 2015 Terence Rajivan Edward http://www.kritike.org/journal/issue 16/edward june2015.pdf ISSN 1908-7330 
cases of unintentional consent. I shall refer to these answers as the meaning answer and the protection answer. Neither answer succeeds.

1. The Meaning Answer. One answer to why unintentional consent is impossible is that if one is using the word 'consent' as we ordinarily do, the very meaning of this word entails that consent must be intentional. Hence, to use this word as we ordinarily do and speak of unintentional consent is to contradict the definition of consent. And if one is not using this word as we ordinarily do, then one is talking about something else, different from what we are talking about when we deny that there can be unintentional consent, or so it will be said by a person who offers this answer. We can call this answer the meaning answer, because it appeals exclusively to the meaning of the word 'consent' to answer the question.

The meaning answer can be contested by adapting an example that Simmons gives of tacit consent. ${ }^{4}$ I shall refer to his example as 'the original boardroom example.' It involves the chairman of a company, at the close of a company board meeting, saying, 'There will be a meeting of the board at which attendance is mandatory next Tuesday at $8 \mathrm{am}$, rather than at our usual Thursday time. Any objections?' The board members remain silent. In remaining silent, Simmons says that they have tacitly consented to the proposed meeting. Tacit consent is consent which is expressed not through performing an action, but through the absence of an action, in this case not raising an objection. Simmons specifies certain conditions that have to be met in order for inaction to be a sign of consent. ${ }^{5}$ One condition he specifies is that there is a reasonable period of time in which objections or expressions of dissent are invited or appropriate. Another condition is that the means for expressing dissent are reasonably easy to perform. There are other conditions, all of which are conceived to be met in the example.

In the example, all board members are aware of the chairman's announcement. I shall now adapt the example in order to dispute the meaning answer. I will refer to the version of it presented in this paragraph as 'the adapted boardroom example'. Imagine that one member of the board stops listening significantly before the close of the meeting and daydreams instead. The chairman clearly makes an announcement about a mandatory meeting next Tuesday and clearly asks if there are any objections, but this person misses the information because he or she is not paying attention. He or she is perfectly capable of paying attention, but he or she does not. He or she is silent during the period in which objections are invited. In this adapted version of Simmons' example, the silence is not an intentional expression of consent, but it is taken as an expression of consent by the

4 Simmons, "Tacit Consent and Political Obligation," 278-279.

${ }^{5}$ Ibid., 279-280.

(c) 2015 Terence Rajivan Edward

http://www.kritike.org/journal/issue 16/edward june2015.pdf

ISSN 1908-7330

(cc) BY-NC-ND 
chairman. Is the chairman mistaken to think that this board member has consented? It would be nothing extraordinary for the board member to later find out about the proposed meeting and be told, 'If you did not object, you consented. You now have to be there.' If not intending to consent entails that the daydreaming board member has not contested, in virtue of the very meaning of the term 'consent,' this needs to be argued for, because it is not at all obvious.

How can one argue for the meaning answer? A standard approach would be to begin with a definition of consent that is beyond reasonable doubt and then show that this definition entails that consent must be intentional. Simmons provides us with the following definition of consent, which is supposed to capture the ordinary meaning of the word 'consent' in the sense that is relevant for his article:

When I speak of consent, then, I mean the consenter's according to another a special right to act within areas where the consenter is normally free to act. ${ }^{6}$

I have doubts about whether this definition is right. But even if it is right, the definition does not say that consent has to be given intentionally; hence, it is also not apparent from this definition that unintentional consent is a contradiction in terms.

In the sentence after the one quoted above, Simmons implies that giving someone else a right to act where the consenter is normally free to act has to be done intentionally:

This is expressed through a suitable expression of the consenter's intention to enter such a transaction, and involves the assuming of a special obligation not to interfere with the exercise of the right accorded. ${ }^{7}$

But to simply assert this is not to argue that consent has to be given intentionally. No one who doubts that it has to be intentional would have any reason to be moved by this assertion alone. Furthermore, I wonder whether examples like the adapted boardroom example did not occur to Simmons and I wonder whether, if they had occurred to him, he would not have made the statement last quoted.

Now an understandable concern is that the adapted boardroom example is not a case of the daydreaming board member consenting, even

${ }^{6}$ Ibid., 276.

${ }^{7} \mathrm{Ibid}$.

(C) 2015 Terence Rajivan Edward http://www.kritike.org/journal/issue 16/edward june2015.pdf ISSN 1908-7330 
tacitly consenting, because to consent to something is to inwardly approve of that thing and the daydreaming board member is not aware of the proposed rescheduled meeting in order to have this attitude. However, Simmons is careful to distinguish the sense of consent which is relevant for his discussion from the sense in which to consent to something is to inwardly approve of that thing:

But this sense of "consent" is quite irrelevant to our present discussion, where we are concerned exclusively with consent in the "occurrence" sense, that is, with consent as an act which may generate obligations. An attitude of approval is completely irrelevant to the rights and obligations of the citizen who has it. When a man consents, he has consented and may be bound accordingly, regardless of how he feels about what he has consented to. ${ }^{8}$

Simmons is surely correct to think that there can be consent, in the sense in which he is interested, without an inner attitude of approval. If an inner attitude of approval were needed, then a person could far too easily deny that they have obligations after giving a sign of consent to something, because they could say that the giving of this sign was not accompanied by inward approval. For example, a person who gives a sign of consent to a meeting so as to not be at odds with the majority could later say that they have no obligations because they did not inwardly approve of the meeting. There should not be such an easy way out of obligations and so an inner attitude of approval cannot be required.

So far then there is no support for the meaning answer as to why unintentional consent is impossible. Furthermore, I think any attempt to establish this answer is going to be open to doubt. On the basis of the adapted boardroom example, it is open to doubt that the meaning of 'consent' implies that if someone consented, they did so intentionally. I do not see how it can be proved that there is this implication.

2. The Protection Answer. There is another answer that can easily be anticipated in response to the question, 'Why say that it is absurd to suppose that there can be unintentional consent?' This answer asserts that the intention requirement is the only barrier to others gaining claims over one's time, energy, body, mind and property. Others can say that you consented and without the requirement that consent has to be given intentionally, you will have no grounds to protest. The requirement that

8 Ibid., 290.

(c) 2015 Terence Rajivan Edward

http://www.kritike.org/journal/issue 16/edward june2015.pdf

ISSN 1908-7330

(cc) BY-NC-ND 
consent be given intentionally is there to protect you from others gaining rights over you and your belongings, a protection that nothing else could give. We can refer to this as the protection answer.

I think this answer is mistaken. There is a different requirement that can also constitute a considerable barrier to others gaining claims over your time, energy, body, mind and property. We can call this different requirement 'the responsibility requirement.' According to it, a person only counts as consenting if he or she is responsible for giving the sign of consent. We do not need the intention requirement to have a barrier, because we can appeal to the responsibility requirement instead. And if we do appeal to the responsibility requirement, we can allow for some cases of unintentional consent, such as in the adapted boardroom example, where the daydreaming board member is responsible for not paying attention.

There is another point that is worth making here. Even if we begin by accepting the intention requirement, there is a challenge that must be dealt with. We must allow for intentional consent to change our rights. Can it not then change our rights in the following way: An act of intentional consent introduces the possibility of unintentional consent in select contexts, which was not there before? ${ }^{9}$ To illustrate this change, imagine that to become a member of a certain company board one has to intentionally consent to various things, including that if one stays silent and does not object to the chairman's proposal, when it has been made clearly and objections have been invited, then one counts as consenting to the proposal regardless of one's intentions. Normally this is not stated explicitly, but there could be a contract in which it is. Does not intentional consent to becoming a member of this board therefore include a change in rights that introduces the possibility of unintentional consent as a board member? Given that an advocate of the protection answer allows for intentional consent to transform our rights, they need to explain why this particular transformation is impossible if they are to deny unintentional consent, and I cannot see any explanation available. (Note that cases of unintentional consent enabled by prior intentional consent are different from the small print cases that we are not counting as genuine unintentional consent. In cases of unintentional consent enabled by prior intentional consent, what is consented to unintentionally is not specified in the contract to which prior intentional consent is given.)

At a certain point in his text, Simmons gives an answer for why one specific form of consent, tacit consent, must be intentional. The answer he gives closely resembles the protection answer. Perhaps it is just a version of

${ }^{9}$ I have taken inspiration here from H.A. Pritchard's account of how promises give rise to obligations. See H.A. Pritchard, "The Obligation to Keep a Promise," in Moral Writings, ed. by H.A. Pritchard and Jim MacAdam (Oxford: Oxford University Press, 2002), 259-260.

(c) 2015 Terence Rajivan Edward

http://www.kritike.org/journal/issue 16/edward june2015.pdf

ISSN 1908-7330

(cc) BY-NC-ND 


\section{UNINTENTIONAL CONSENT}

this answer. So far we have no reason to think that the protection answer works. In the next section, I will show that Simmons does not adequately justify the answer he gives.

\section{Simmons' Argument}

The overall aim of Simmons' article is to evaluate consent theories of political obligation, which he refers to as consent theories for short. According to a consent theory of political obligation, we have obligations to obey the government because we have consented to do as it says. Now since most of us do not explicitly consent, the proponent of this kind of theory traditionally appeals to tacit consent. They say that we tacitly consent to follow the government's commands. In order to evaluate this appeal to tacit consent as the source of political obligations, Simmons tries to provide an account of tacit consent in general: what it is and what conditions must be obtained in order for it to be given. The original boardroom example is introduced as part of developing this general account. He then goes on to consider whether the general account he develops, when applied to the specific case of tacit consent to the government, results in a plausible theory of political obligation. He denies that it does.

Before making this denial, Simmons presents an argument that tacit consent can only be a source of political obligation if tacit consent to anything must be given intentionally:

... consent theory's account of political obligation is appealing only if consent remains a clear ground of obligation, and if the method of consent protects the individual from becoming politically bound unknowingly or against his will. It seems clear that these essential features of a consent theory cannot be preserved if we allow that tacit consent can be given unintentionally. ${ }^{10}$

To be politically bound, as the expression is used here, means to have an obligation to obey the government. Simmons thinks that a consent theorist of political obligation has to accept the following argument:

(1) There can be cases of political obligation resulting from tacit consent.

10 Simmons, “Tacit Consent and Political Obligation," 281.

(C) 2015 Terence Rajivan Edward

http://www.kritike.org/journal/issue 16/edward june2015.pdf

ISSN 1908-7330

(cc) BY-NC-ND 
(2) There can only be cases of political obligation resulting from tacit consent if tacit consent to government authority protects an individual from becoming politically bound unknowingly or against their will.

(3) Tacit consent to government authority can only protect an individual from becoming politically bound unknowingly or against his or her will if tacit consent to anything cannot be given unintentionally.

From (2) and (3):

(4) There can only be cases of political obligation resulting from tacit consent if tacit consent to anything cannot be given unintentionally.

From (1) and (4):

(5) Tacit consent to anything cannot be given unintentionally.

This argument seems very similar to saying, 'We cannot allow for there to be unintentional consent to one particular thing unless we allow for there to be unintentional consent to anything and we do not want to allow for that.' It is worth noting that Simmons himself accepts the (1) to (5) argument. He accepts that there can be political obligations from consent. His difficulty with consent theories of political obligation is that he does not think that there are enough consenters, either explicit or tacit, for this kind of theory to work; ${ }^{11}$ or at least that was his view at the time. ${ }^{12}$

The objection I wish to make to this argument concerns premise (3): the premise that tacit consent to government authority can only protect an individual from becoming politically bound unknowingly or against his or her will if tacit consent to anything cannot be given unintentionally. Presumably, this premise is false if there can be unintentional tacit consent to some things yet there cannot be political obligations arising from unintentional tacit consent. This combination would mean that tacit consent does not have to always be intentional in order for one to not be at risk from becoming politically bound unknowingly or against one's will by tacit consent. Now consent theorists must allow that consent sometimes does not generate obligations. One kind of example is if one consents to do something radically evil to another. One is not now obliged to carry out the action. There are other kinds of example where consent does not generate

${ }^{11}$ Ibid., 290.

12 For criticism of his earlier view, see A. John Simmons, "Consent Theory for Libertarians," in Social Philosophy and Policy, 22: 1 (2005), 346-347.

(c) 2015 Terence Rajivan Edward http://www.kritike.org/journal/issue 16/edward june2015.pdf ISSN 1908-7330 


\section{UNINTENTIONAL CONSENT}

obligations, notably when it is the consenter who is in need of basic protection. (Consider, for instance, the case of a child who consents to hard labour.) If becoming politically bound unknowingly or against one's will is such a bad thing, I think there is room for the believer in unintentional tacit consent to say that no political obligation can arise from unintentional tacit consent, while maintaining that there are other obligations that can arise from it. Anyone who wishes to deny that there is room for this move needs to justify their denial, but Simmons provides no justification.

At present the two answers that can be anticipated for why unintentional consent is impossible are unconvincing and the closest Simmons offers to an answer, his argument against unintentional tacit consent, is no better. In light of the adapted example I have given, the onus is on those who think that unintentional consent is impossible to provide a compelling reason against this possibility. I cannot find any reason that serves to rule out the possibility.

\section{Terminological Note}

I have defined unintentional consent in a way that, I think, captures what Simmons and Feinberg mean by 'unintentional consent' when they claim that unintentional consent is absurd. There is a subtle literature on when an action is unintentional, ${ }^{13}$ and perhaps Simmons and Feinberg have used the word 'unintentional' in a way that does not fit well with some strands of this literature. But I would be careful about transferring points from this literature to the context of the consent literature, because the crucial issue for evaluating Simmons and Feinberg's claim is whether there can be unintentional consent as defined here.

School of Social Sciences, University of Manchester, United Kingdom

\section{References}

Feinberg, Joel, "Civil Disobedience in the Modern World," in Freedom and Fulfilment: Philosophical Essays (Princeton: Princeton University Press, 1994).

John Simmons, A., “Consent Theory for Libertarians," in Social Philosophy and Policy, 22: 1 (2005).

John Simmons, A., "Tacit Consent and Political Obligation," in Philosophy and Public Affairs, 5:3 (1976).

${ }^{13}$ E.g. Ryan Wasserman, "Intentional Action and the Unintentional Fallacy," in Pacific Philosophical Quarterly, 92:4 (2011), and Alfred Mele, "Intentional, Unintentional, or Neither? Middle Ground in Theory and Practice," in American Philosophical Quarterly, $49: 4$ (2012).

(c) 2015 Terence Rajivan Edward

http://www.kritike.org/journal/issue 16/edward june2015.pdf

ISSN 1908-7330

(cc) BY-NC-ND 
Mele, Alfred, "Intentional, Unintentional, or Neither? Middle Ground in Theory and Practice," in American Philosophical Quarterly, 49:4 (2012).

Pritchard, H.A., "The Obligation to Keep a Promise," in Moral Writings, ed. by H.A. Pritchard and Jim MacAdam (Oxford: Oxford University Press, 2002).

Raz, Joseph, The Morality of Freedom (Oxford: Clarendon Press, 1986).

Wasserman, Ryan, "Intentional Action and the Unintentional Fallacy," in Pacific Philosophical Quarterly, 92: 4 (2011). 